\title{
PEMBAHARUAN ATAS HUKUM KELUARGA DI INDONESIA: SATU TINJAUAN SOSIOLOGIS
}

\author{
Munawir Haris \\ Jurusan Syariah STAIN Sorong Papua Barat \\ Email: irfani.fanani@gmail.com
}

\begin{abstract}
The renewal of Islamic law is essentially contrary to something that already exists (existing) then undergoes a qualitative change as a product of interaction in public life. It could be argued that the process of renewal of Islamic law is seen as something autonomous, but it also interacts with other elements in society that occur interdependently. Therefore, the concept of renewal of Islamic law requires adaptive stance with social conditions in which it interacts. In this case, the realization of the principle of almubăfazatu 'alà al-qadimi al-șälị̀ wa al-akhdhu bi al-jadìd al-ạlah. (Maintaining the old one if it is still good and accept the new or changed if it is considered better) became a necessity. Within the framework of family law renewal in Indonesia, Islamic law has a very strategic and important role. From the sociological point of view, Islamic family law has deeply rooted in the Muslim daily live and become a living law in the midst of the majority of Indonesian people. Renewal of Islamic law in the context of family law in Indonesia includes four categories namely figh, fatwa a, jurisprudence and legislation. This article explores these four categories and shows how reform influence these domains.
\end{abstract}

Keywords: Renewal, Islamic law, family law, Indonesia, sociological perspective.

DOI: http:/ / dx.doi.org/10.20414/ ujis.v19i1.1254

\section{Pendahuluan}

SYARIAT Islam dengan kedua sumber pokok al-Qur'an dan Sunnah, tidak lahir dalam masyarakat yang hampa kultur. Keduanya, disamping sebagai konsep ilahi yang mengajarkan kebenaran, sekaligus menjadi pedoman hidup dan kehidupan manusia. Syariat Islam pada hakikatnya bersifat universal. Di 
dalamnya ada dimensi hukum yang menuntut perubahan, modifikasi dan pembaruan. Tujuan diciptakan syariat Islam adalah terwujudnya suatu kemaslahatan di tengah-tengah masyarakat dengan tidak mengenal batasan ruang dan waktu. ${ }^{1}$ Dari sini, maka dianggap wajar adanya gagasan figh mazhab nasional ${ }^{2}$ atau fiqh Indonesia ${ }^{3}$ walaupun pada mulanya terjadi reaksi dari pihak-pihak yang menentangnya. ${ }^{4}$

Pembaruan hukum Islam pada dasarnya bertolak pada sesuatu yang telah ada (existing), kemudian mengalami perubahan secara kualitatif sebagai produk interaksi dalam kehidupan masyarakat. Proses pembaruan hukum Islam, dipandang sebagai sesuatu yang otonom, sekaligus berinteraksi dengan unsur lain dalam masyarakat, sehingga terjadi saling bergantung. Ketika hukum Islam berinteraksi dengan kehidupan sosial masyarakat, selalu dihadapkan dengan sejumlah pesoalan, baik yang bersifat internal maupun eksternal. Oleh karena itu, konsep pembaruan hukum Islam menuntut adanya sikap adaptatif dengan kondisi sosial masyarakat di mana berinteraksi. Dalam hal ini, perwujudan kaidah al-muhäfaz̧atu 'alà al-qadìm al-șälih wa al-akbdhu bi al-jadidi al-aslah. (memelihara yang lama jika hal itu masih baik dan menerima yang baru atau perubahan jika hal itu dianggap lebih baik), menjadi sangat relevan. Hal ini penting, karena prilaku mukallaf yang menjadi objeknya dipandang sebagai sesuatu yang kontinum dan senantiasa mengalami perubahan.

Pembaruan hukum Islam harus dilakukan dalam memberikan respon terhadap tuntutan perubahan yang terjadi di tengah-tengah masyarakat. Bentuk dari universalitas hukum Islam dilihat dari daya adaptabilitas dan fleksibilitas hukum Islam

1Abū Ishāiq al-Shathībī, al-Muwāfaqāt fì Usūl al-Sharāah, ed. Taḥqiq Abdullah Daraz, vol. 2 (Beirut: Dār al-Kutub al-'Ilmiyyah, t.th.), 3-7.

2Idea ini dimunculkan oleh Hazairin (1905-1975). Lihat Hazairin, Tujuh Serangkeai tentang Hukum (Jakarta: Tintamas, 1974).

3 Gagasan fiqh Indonesia dimunculkan oleh Hasbi As Shiddiqiy (19061976). Lihat Hasbi As Shiddiqiy, Syariat Islam Menjawab Tantangan Zaman (Jakarta: Bulan Bintang, 1996), 43.

${ }^{4}$ Dalam hal ini diwakili oleh Ali Yafie dan Ibrahim Hosen. Lihat Ali Yafie, "Matarantai yang Hilang," Pesantren 2, no. 2 (1985): 30. Lihat pula Ibrahim Hosen, "Pemerintah sebagai Mazhab," Pesantren 2, no. 2 (1985): 456. 
itu sendiri. Itu berarti, bahwa pemikiran hukum Islam tidak kostan dalam satu zaman, tempat dan keadaan, melainkan senantiasa mengalami perubahan secara dinamis seiring dengan perubahan zaman, tempat dan keadaan. Hal ini sesuai dengan pendapat Al-Jawziyah yang mengatakan bahwa " تغبـر القتـاوى "

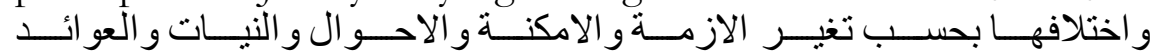
(Perubahan ide-ide atau pemikiran hukum dan perbedaannya sessuai dengan perubahan zaman, ruang, keadaan, niat, dan kebutuhan)." Lebih jauh al-Jawziyah mengatakan, bahwa tidak memahami (mempertimbangkan, pen.) perubahan, merupakan kesalahan besar dalam syariat. ${ }^{5}$ Kendatipun pembaruan hukum Islam dipandang sebagai suatu keharusan, tetapi perlu ditegaskan bahwa pembaruan hukum Islam yang meliputi segala bentuk mu'amalah diizinkan oleh syariat Islam, sepanjang tidak kontra produktif dengan jiwa dan roh hukum Islam itu sendiri. Dikatakan demikian karena hukum Islam dalam bidang mu'amalah hanya mengatur dan menetapkan prinsip-prinsip pokoknya secara umum, sedangkan perinciannya diserahkan kepada manusia untuk memikirkannya, dengan catatan tetap berangkat dari prinsip dasar yang dikehendaki oleh hukum Islam itu sendiri. Dalam hal ini, dapat dikatakan bahwa jiwa dan prinsip hukum Islam bersifat konstan, permanen, stabil dan tidak berubah sepanjang masa. Akan tetapi, terhadap peristiwa hukum, teknis dan cabang-cabangnya, dapat mengalami perubahan atau pembaruan sesuai dengan tuntutan zaman. ${ }^{6}$

Salah satu aspek yang sangat penting dalam kehidupan mu'amalah adalah masalah hukum keluarga. Dalam kaitan ini J.N.D. Anderson mengatakan hukum keluarga dianggap sebagai inti syariat, karena bagian inilah yang oleh umat Islam dianggap sebagai pintu gerbang untuk masuk lebih jauh ke dalam wilayah

5Ibn al-Qayyim al-Jawziyah, I'lam al-Muwaqqin 'an Rabb al-'Alamin, vol. 3 (Beirut: Dār al-Fikr, t.th.), 14.

6Rahmat Djatnika, "Jalan Mencari Hukum Islam Upaya Ke Arah Pemahaman Metodologi Ijtihad," in Dimensi Hukum Islam Dalam Sistem Hukum Nasional, ed. Amrullah Ahmad SF (Jakarta: Gema Insani Press, 1996), 106-7. 
agama dan masyarakat. ${ }^{7}$ Hukum keluarga sebagai bagian penting dalam hukum Islam, tidak luput dari gagasan pembaruan sebagaimana dengan bagian hukum Islam lainnya. Bahkan, pembaruan hukum keluarga Islam telah menjadi wacana yang mengglobal di seluruh dunia Islam, khususnya di Indonesia. Dalam artian bahwa pembaruan hukum Islam telah menjadi suatu isu dari gerakan modernisasi yang paling hangat dibicarakan di dunia Islam. Kendatipun demikian, dalam prosesnya tidak dapat terlepas dari berbagai aspek yang mengitari gagasan pembaruan hukum keluarga Islam.

Dalam kontes tersebut, paling tidak terdapat dua faktor, yaitu faktor internal dan faktor eksternal. Faktor internal adalah terjadinya perbedaan antara umat Islam sendiri dalam memaknai pembaruan hukum Islam, baik secara substantif maupun secara metodologis. Sedangkan faktor eksternal adalah kehidupan sosial masyarakat yang mengitarinya, bahkan termasuk faktor kekuasaan negara. Dengan demikian, fokus permasalahan yang akan dikaji dalam artikel ini adalah terkait dengan masalah pembaharuan hukum Islam dan berbagai aspek hukum keluarga di Indonesia khususnya.

\section{Paradigma Pembaruan Hukum Islam di Indonesia}

Secara garis besarnya, hukum Islam meliputi empat bidang, yaitu: pertama, bidang ibadah, yakni merupakan penataan hubungan antara manusia dengan Allah Swt. Kedua, bidang munakahah, merupakan penataan hubungan antara manusia dalam lingkungan keluarga. Ketiga, bidang mu'amalah, merupakan penataan hubungan antarmanusia dalam pergaulan hidup masyarakat. Keempat, bidang jinayah, merupakan penataan pengamanan dalam suatu tertib pergaulan yang menjamin keselamatan dan ketentraman dalam kehidupan masyarakat. ${ }^{8}$ Sedangkan menurut A. Jazuli, hukum Islam meliputi: bidang ibadah, bidang abwäl al-Shakhsiyah (perkawinan, kewarisan, wasiat, dan wakaf), bidang mu'amalah (dalam arti sempit),

7J.N.D. Anderson, Islamic Law in Modern World, trans. Machnun Husain (Surabaya: Amar Press, 1991), 42.

${ }^{8}$ Ali Yafie, Menggagas Fiqh Sosial (Jakarta: Logos Wacana Ilmu, 1995), 132. 
bidang jinayah, bidang aqdhiyah (peradilan), dan bidang siyasah (dusturiyah, mäliyah, dan dawliyah). ${ }^{9}$

Pembidangan hukum Islam tersebut, sejalan dengan perkembangan pranata sosial, sebagai norma yang berfungsi untuk memenuhi kebutuhan manusia dalam kehidupan individual dan kolektif. Oleh karena itu, semakin beragam kebutuhan hidup manusia dan semakin beragam pranata sosial, maka semakin berkembang pula pemikiran ulama dan pembidangan hukum Islam pun mengalami pengembangan. $\mathrm{Hal}$ itu menunjukkan, terdapat korelasi positif antara perkembangan pranata sosial dengan pemikiran ulama secara sistematis. Atau sebaliknya, penyebarluasan produk pemikiran ulama yang mengacu kepada firman Allah melahirkan berbagai pranata sosial. ${ }^{10}$

Hukum Islam yang termaktub di dalam ayat-ayat ahkam, hadis-hadis ahkam, dan terutama di dalam kitab-kitab fiqh dipahami terus mengalami perkembangan dan pengembangan. Dalam proses pengembangan, hukum Islam mengalami internalisasi ke dalam berbagai pranata sosial yang tersedia di dalam masyarakat. Terjadi proses alokasi hukum Islam, dalam dimensi syari'ah ke dalam pranata sosial, menjadi landasan dan memberi makna serta arah dalam kehidupan masyarakat Islam Indonesia. Hasil dari proses pengembangan hukum Islam yang terjadi dalam rentang waktu berabad-abad, berkembang berbagai pranata sosial yang bercorak keislaman. ${ }^{11}$

Pranata-pranata sosial dapat dilihat dari dua sudut pandang, yaitu: pertama, ia merupakan aktualisasi hukum Islam yang tertumpu kepada interaksi sosial yang mempola setelah mengalami pergumulan dengan kaidah-kaidah lokal yang dianut oleh masyarakat Indonesia yang majemuk. Dalam pergumulan itu, terjadi adaptasi dan modifikasi antara hukum Islam dengan kaidah lokal. Dengan perkataan lain bahwa proses sosialisasi dan institusionalisasi hukum Islam terjadi dalam hubungan timbal

9A. Jazuli, Ilmu Fiqh: sebuah Pengantar (Bandung: Orba Shakti, 1991), 54.

${ }^{10} \mathrm{Cik}$ Hasan Bisri, Hukum Islam dalam Tatanan Masyarakat Indonesia (Jakarta: Logos, 1988), 115.

11Ibid., 116. 
balik dengan kaidah-kaidah lokal yang dianut. Selain itu, terjadi intervensi hukum barat terutama sejak masa penjajahan Belanda.

Kedua, pranata-pranata sosial merupakan perwujudan interaksi sosial di dalam masyarakat Islam untuk memenuhi kebutuhan hidup mereka. Interaksi sosial itu berpatokan dan mengacu kepada keyakinan (kesepakatan tentang benar dan salah), nilai (kesepakatan tentang baik dan buruk), dan kaidah (kesepakatan tentang yang mesti dilakukan dan yang mesti ditinggalkan), yang dianut oleh mereka. Ia merupakan perwujudan amal shaleh sebagai ekspresi keimanan dalam interaksi sosial. ${ }^{12}$

Dalam kehidupan masyarakat Islam Indonesia dewasa ini, dikenal berbagai pranata sosial yang bercorak keislaman. Pranata-pranata sosial meliputi berbagai bidang kehidupan, yang senantiasa mengalami perkembangan dari waktu ke waktu. Ada pranata yang amat dekat dengan keyakinan yang dianut, sehingga memiliki tingkat kepekaan yang sangat tinggi, seperti pranata peribadatan, pranata kekerabatan, dan pranata pendidikan. Ada pula pranata sosial yang relatif agak jauh dari keyakinan, sehingga relatif luwes atau netral, seperti pranata ekonomi dan pranata keilmuan, sehingga proses adaptasinya relatif longgar dan labelnya sebagai hukum Islam bersifat luwes. Selanjutnya pranata-pranata sosial mengalami kongkretisasi dalam struktur masyarakat, dalam bentuk berbagai organisasi sosial sebagai wahana untuk memenuhi kebutuhan hidup secara kolektif dan terencana. Kenyataan itu menunjukkan bahwa di dalam masyarakat terjadi penyerapan produk teknologi sosial (pengorganisasian masyarakat) mutakhir, dan dapat dijadikan saluran untuk mengaktualisasikan hukum Islam di dalam kehidupan nyata. ${ }^{13}$ Dengan demikian, pembaruan hukum Islam sebagai aktualisasi perintah Allah mempunyai beragam bentuk dan mencakup beragam pranata sosial. Oleh karena itu, pembaruan hukum Islam di Indonesia terpola pada internalisasi hukum Islam ke dalam pranata-pranata sosial atau sebaliknya pranata sosial terinternaliosasi ke dalam hukum Islam. Pada

12Ibid., 117.

13Ibid., 118. 
konteks ini, tampak relasi yang saling mendukung antara hukum Islam dan pranata sosial.

Dalam konteks tersebut, pembaruan hukum Islam di Indonesia meliputi empat kategori, yaitu:

\section{Fiqh}

Salah satu wujud hukum Islam yang sistematis dan rinci adalah fiqh. ${ }^{14}$ Secara garis besarnya fiqh meliputi empat bidang, yaitu: pertama, ibadah merupakan penataan hubungan antara manusia dengan Tuhan. Kedua, bidang munakahat yang merupakan penataan hubungan antarmanusia dalam lingkungan keluarga. Ketiga, bidang mu'amalah merupakan penataan hubungan antarmanusia dalam pergaulan kemasyarakatan. keempat, bidang jinayah merupakan penataan pengamanan dalam suatu tertib pergaulan yang menjadi keselamatan dan ketenteraman dalam hidup bermasyarakat. ${ }^{15}$

Fiqh sebagai produk pemikiran hukum Islam, baru berkembang pada masa sahabat sepeninggal Rasulullah. Hal itu disebabkan oleh karena pada masa kenabian karena setiap persoalan yang ada dengan mudak dapat diselesaikan oleh nabi

${ }^{14}$ Secara etimologis fiqh berarti paham yang mendalam. Sedangkan menurut Hasbi Ash-Shiddiqy, fiqh adalah ilmu syariat. Al-Amīdìy mendefenisikan figh sebagai ilmu tentang seperangkat hukum-hukum syara' yang bersifat furu'yyah yang didapat melalui penalaran atau istidlal. Dalam banyak hal, fiqh selalu diidentikkan dengan hukum Islam. Pengidentikkan ini telah melahirkan suatu kekeliruan dalam penerapannya. Dikatakan demikian karena pada dasarnya kedua istilah ini memiliki makna yang berbeda, fiqh hanyalah salah satu bagian dari hukum Islam. Oleh Abd. Wahab Khallaf, fiqh adalah pengetahuan tentang hukum-hukum syariah Islam mengenai perbuatan manusia yang diambil dari dalil-dalil yang detail. Sedangkan dalam proses perkembangannya fiqh lebih dikesankan sebagai produk pemikiran manusia. Dalam istilah lain, fiqh merupakan hasil interpretasi manusia dari dalil-dalil hukum, sedangkan hukum Islam atau syari’ah lebih dikesankan sebagai hukum-hukum qath'iy yang tidak interpretatif. Lihat, M. Hahya Harahap, "Informasi Materi Kompilasi Hukum Islam: Mempositifkan Abstraksi Hukum Islam," in Kompilasi Hukum Islam dan Peradilan Agama dalam Sistem Hukum Nasional, ed. Cik Hasan Bisri (Jakarta: Logos Wacana Ilmu, 1999), 21, 3. Lihat pula, Ahmad Hanafi, Sejarah dan Pengantar Hukum Islam (Jakarta: Bulan Bintang, 1986), 9.

${ }_{15}$ Yafie, Menggagas Fiqh, 132. 
sendiri melalui wahyu dan sabda-sabdanya (baca; hadis). Muncul dan berkembangnya kajian-kajian fiqh disebabkan oleh muncul persoalan-persoalan akibat semakin meluasnya wilayah Islam dan semakin besarnya jumlah umat Islam dengan latar belakang etnis dan kultur yang berbeda. Oleh karena masalah-masalah yang muncul itu belum pernah dialami oleh Rasulullah dan tidak terdapat naș secara jelas dan tegas tentang hal itu, maka para sahabat dan generasi berikutnya dituntut untuk berpikir dalam menyelesaikan masalah-masalah yang ada.

Sekaitan dengan hal tersebut, fiqh sebagai produk pemikiran hukum Islam di Indonesia, karakteristiknya sangat kental dengan kepribadian Arab. Hal itu disebabkan oleh karena jaringan intelektual para fuqaha Indonesia terlalu Arab oriented. Kondisi seperti ini berlangsung hingga paro pertama abad ke-20.16 Pada konteks ini, Hasbi Ash-Shiddiqy mengatakan bahwa terdapat bagian-bagian fiqh kaum Muslimin Indonesia yang didasarkan pada urf timur tengah yang tidak sesuai dengan rasa kesadaran hukum masyarakat Indonesia yang melembaga dalam hukum adat. Atas dasar itulah sehingga fiqh kurang mendapat sambutan hangat dari masyarakat Indonesia, karena dianggap tidak sesuai dengan kepribadian bangsa Indonesia. ${ }^{17}$

Keterasingan fiqh itu sebagaimana yang disinyalir oleh Hasbi ash-Shiddiqy tersebut antara lain juga disebabkan oleh pandangan fiqh yang terlalu formalistik. Kecenderungan fiqh yang demikian menjadikannya sebagai paradigma kebenaran ortodoks, di mana semua realitas tunduk pada kebenaran fiqh. Penekanan yang terlalu berlebihan pada formalisme dan

16Marzuki Wahid and Rumadi, Fiqh Mą̧ab Negara (Yogyakarta: LKiS, 2001), 129.

${ }^{17}$ Selengkapnya Hasbi Ash-Shiddiqy mengatakan "fiqh yang berkembang dalam masyarakat kita sekarang, sebagiannya adalah fiqh Hijazi yaitu fiqh yang terbentuk atas dasar adat istiadat yang berlaku di Hijaz atau fiqh Misryi, yaitu fiqh yang terbentuk atas dasar adat istiadat dan kebiasaan di Mesir, atau fiqh Hindy yaitu fiqh yang terbentuk berdasarkan adat kebiasaan yang berlaku di India. Selama ini kita belum menunjukkan kemampuan untuk berijtihad untuk mewujudkan fiqh yang sesuai dengan kepribadian Indonesia, karena itu kadang-kadang kita paksakan fiqh Hijazi atau fiqh Misry dan lain-lain untuk berlaku di Indonesia atas dasar taklid. Lihat, As Shiddiqiy, Syariat Islam, 41-2. 
kecenderungan melakukan teologisasi fiqh, menyebabkan fiqh Indonesia seolah-olah menjauhi diri dari realitas sosial dan kultur masyarakat yang menjadi objeknya. ${ }^{18}$ Oleh karena itu, sudah saatnya dipikirkan upaya untuk menggeser paradigma fiqh ortodoksi kepada paradigma fiqh berwawasan sosial-budaya, yaitu melakukan pembaruan paradigma fiqh yang ramah dengan kultur dan budaya bangsa Indonesia dengan tetap berpegang pada prinsip-prinsip universal hukum Islam, yaitu memelihara agama, akal, jiwa, kehormatan dan harta. Jika paradigma pertama memperlihatkan hitam-putih dalam memandang realitas, maka yang kedua memperlihatkan watak yang bernuansa kultural. Kiranya gagasan Gus-Dur tentang pribumisasi Islam patut mendapat sambutan dan kajian lebih jauh dalam upaya pembaruan fiqh sebagai produk pemikiran hukum Islam yang berwawasan budaya yang mempertimbangkan kearifan-kearifan lokal.

\section{Fatwā}

Fatwā adalah hasil ijtihad seorang mufti sehubungan dengan peristiwa hukum yang diajukan kepadanya. Produk pemikiran hukum Islam dalam kategori fatwā, di antara cirinya ialah bersifat kasuistik, karena merupakan respon atau jawaban atas pertanyaan yang diajukan oleh peminta fatwā. Berbeda dengan putusan pengadilan, fatwā tidak mempunyai daya ikat dan daya paksa, dalam arti bahwa yang meminta fatwā tidak harus mengikuti isi atau hukum yang diberikan kepadanya. Demikian pula masyarakat luas tidak harus terikat dengan fatwā itu, karena fatwā seorang ulama di suatu tempat bisa saja berbeda dengan fatwā ulama lain di tempat yang sama. Biasanya fatwā cenderung bersifat dinamis karena merupakan respon terhadap perkembangan baru yang sedang dihadapi oleh orang atau kelompok yang meminta fatwā. Isi suatu fatwā belum tentu dinamis, tetapi sikap responnya itu sekurang-kurangnya dapat dikatakan dinamis. Meskipun fatwā itu dikeluarkan secara kasuistik, namun sejumlah fatwā dari ulama besar atau lembaga

${ }^{18}$ Ibid., 130-1. 
keagamaan dan hukum telah dibukukan, tetapi sistematikanya tetap berbeda dengan fiqh. ${ }^{19}$

Dalam sejarah, pelaksanaan pemberian fatwā dimulai sejak agama Islam meluaskan wilayah pengaruhnya pada abad ke-7 dan ke-8. Kaum Muslimin menghadapi berbagai persoalan yang membutuhkan penyelesaian hukum terhadap persoalanpersoalan baru dengan cepat. Bagi mereka yang tinggal di kotakota besar, umumnya mereka menyelesaikan persoalanpersoalan yang dihadapi melalui lembaga peradilan atau hakimhakaim yang dapat menyelesaian persoalannya. Akan tetapi bagi meraka yang tinggal jauh dari kota-kota besar, baisanya dalam menyelesaikan persoalannya cukup bertanya atau meminta fatwā kepada orang yang dianggap pintar. ${ }^{20}$

Di Indonesia, pembaruan hukum Islam dalam kategori fatwā dilakukan oleh organisasi-organisasi kemasyarakatan seperti NU, MUI, Muhammadiyah dan Persis. ${ }^{21}$ Masing-masing organisasi mempunyai lembaga khusus yang melakukan pembaruan hukum Islam dalam bentuk fatwā. Dalam lingkungan NU adalah pembaruan hukum Islam dalam bentuk fatwā dilakukan Mejelis Syuriah dan majelis Ablu al-Hall wa al-Aqdi, di lingkungan MUI adalah Komisi Fatwā, di lingkungan Muhammadiyah adalah Majelis Tarjih dan di lingkungan Persis adalah Dewan Hisbah. Pembaruan hukum Islam melalui organisasi ini memiliki kegunaan praktis terutama bagi yang membutuhkannya, baik oleh pmerintah maupun oleh para pemimpin dan anggota masyarakat, pada gilirannya fatwā dapat menjadi acuan dalam penerapan hukum Islam. ${ }^{22}$

\section{Putusan hakim/Peradilan Agama (Yurisprudensi)}

Dalam kepustakaan hukum Anglo Saxon perkataan yuisprudensi mengandung arti yang lebih luas dari perkataan 3.

${ }^{19}$ Muh. Atho Mudzhar, Fatwa-Fatwa Majelis Ulama (Jakarta: INIS, 1993),

20Ibid., 2.

${ }^{21}$ Selain itu, fatwa dapat pula dilakukan oleh pengadilan dalam lingkungan peradilan Agama sebelum berlakunya Undang-Undang No. 7 tahun 1989, khususnya di bidang kewarisan, hibah, wasiat, harta bersama dan kedudukan anak.

${ }^{22}$ Bisri, Aspek-Aspek Sosiologi...., 130-131. 
yurisprudensi dalam hukum Eropa Kontinental. Di dalam kepustakaan anglosaxon, yurisprudensi selain bermakan hukum (dalam putusan) hakim, juga bermakna filsafat hukum dalam ilmu hukum. Sedangkan dalam kepustakaan Eropa kontinental dan dalam kepustakaan hukum Indonesia, yang disebut yurisprudensi adalah kumpulan keputusan Mahkamah Agung (dan Pengadilan Tinggi) mengenai perkara tertentu berdasarkan pertimbangan (kebijaksanaan) hakim sendiri yang diikuti sebagai pedoman oleh lain dalam memutus perkara yang sama atau hampir sama. ${ }^{23}$

Pembaruan produk pemikiran hukum Islam melalui yurisprudensi dipandang perlu dan baik. Dikatakan demikian karena yurisprudensi selain menggambarkan keadilan yang tumbuh dan berkembang dalam masyarakat, juga selaras dengan kesadaran hukum masyarakat Muslim Indonesia, dengan catatan bahwa hakaim peradilan Agama yang membuat yurisprudensi itu, selaim paham benar tentang hukum Islam, juga memperhatikan dengan sungguh-sungguh nilai-nilai hukum pada umumnya yang terdapat dalam masyarakat.

Lebih jauh dapat dikatakan bahwa pembaruan hukum Islam melalui yurisprudensi dianggap sebagai sesuatu yang baik, didasarkan atas beberapa alasan bahwa putusan hakim (yurisprudensi) mempunyai kekuatan mengikat, terutama kalau putusan itu dikeluarkan oleh Pengadilan Tinggi atau Mahkamah Agung. ${ }^{24}$ Di samping itu, yurisprudensi secara psikologis dapat diterima oleh masyarakat karena ia lahir dari suatu perkara yang secara langsung terjadi dalam masyarakat. Itu artinya bahwa yurisprudensi lebih menyentuh masalah-masalah praktis dalam tatanan sosial kemasyarakatan.

Dalam konteks tersebut, yurisprudensi sebagai produk pemikiran hukum Islam dapat dikatakan sangat dinamis karena merupakan respon terhadap perkara-perkara nyata yang dihadapi masyarakat. Keputusan-keputusan peradilan Agama memang tidak meliputi semua aspek pemikiran hukum Islam sebagaimana halnya dengan fiqh, tetapi dari segi kekuatan hukumnya ia lebih mengikat terutama bagi pihak-pihak yang telah berperkara.

${ }^{23}$ Muhammad Daud Ali, Hukum Islam dan Peradilan Agama: Kumpulan Tulisan (Jakarta: Raja Grafindo Persada, 1997), 358.

${ }^{24}$ Ibid., 360. 


\section{Peroduk Perundang-Uundangan}

Peraturan perundang-undangan sebagai salah satu wujud pembaruan hukum Islam, seperti halnya dengan yurisprudensi atau putusan pengadilan yang bersifat mengikat. Bahkan daya ikatnya lebih luas dalam masyarakat, karena tidak hanya pada pihak-pihak tertentu, tetapi seluruh masyarakat yang ada di wilayah hukumnya. Unsur-unsur yang terlibat dalam perumusan perundang-undangan tidak terbatas pada golongan ulama (fuqaba) saja, tetapi melibatkan unsur-unsur lain dalam masyarakat seperti cendikiawan, politisi dan lain-lain. Masa berlakunya suatu Undang-Undang, berlangsung sampai ada peraturan perundang-undangan baru yang menggantikannya. ${ }^{25}$

Di antara produk pemikiran hukum Islam yang telah diakomodasi dalam kategori peraturan perundang-undangan antara lain; Undang-Undang Nomor 1 Tahun 1974 tentang perkawinan, Instruksi Presiden Nomor 1 Tahun 1991 tentang Kompilasi Hukum Islam yang mengatur tentang kewarisan, perkawinan, perwakafan, hibah, sadakah dan wasiat, dan lainlain. Sebagai produk pemikiran hukum Islam, undang-undang memberikan sanksi hukum terhadap orang yang melakukan pelanggaran. Sebagaimana produk kolektif, Undang-Undang memiliki daya ikat yang lebih luas dari keputusan pengadilan. Dalam hal ini yang terpenting harus dimiliki oleh undangUndang sebagai produk pemikiran hukum Islam adalah kualitas yang tinggi dan dapat mencerminkan realitas hukum yang tumbuh dan berkembang dalam masyarakat.

Terlepas dari perdebatan mengenai legitimasi yuridis Kompilasi Hukum Islam (KHI), terdapat beberapa ketentuan hukum yang dikategorikan sebagai pembaruan hukum keluarga Islam di Indonesia, antara lain: ta'lik talak yang terdapat pada pasal 45, pengaturan tentang harta bersama atau gono gini yang terdapat pada pasal 85-97, ketentuan tentang ahli waris pengganti untuk cucu yatim yang terdapat pada pasal 185, ketentuan tentang wasiat wajibah untuk anak dan orang tua

${ }^{25}$ Mudzhar, Fatwa-fatwa Majelis Ulama, 3. 
angkat yang terdapat pada pasal 209, ketentuan tentang harta hibah sebagai warisan yang terdapat pada pasal $221 .{ }^{26}$

Dalam kaitannya dengan hal tersebut, pembaruan hukum Islam di Indonesia dilakukan dalam dua jalur, yaitu jalur struktural dan kultural. Jalur struktural pembaruan hukum Islam dihadapkan pada kekuasaan Negara. Hal ini berarti bahwa pembaruan hukum Islam dilakukan melalui intervensi kekuasaan negara. Intervensi negara terhadap pembaruan hukum Islam terdapat dua keniscayaan, yaitu boleh jadi menguntungkan dan boleh jadi merugikan. Sedangkan pembaruan hukum Islam melalui jalur kultural, dilakukan oleh lembaga-lembaga keagamaan, seperti NU, Muhammadiyah, MUI, dan lain-lain.

\section{Beberapa Aspek Pembaruan Hukum Keluarga Islam di Indonesia}

Pembaruan hukum keluarga Islam merupakan kebutuhan yang harus segera direspon sebagai upaya memberikan jawaban terhadap problema kontemporer. Formulasi hukum keluarga Islam yang tertuang dalam kitab-kitab fiqh bukan rumusan baku yang tidak boleh berubah, melainkan harus dipandang sebagai penafsiran atau rumusan para ulama pada zamannya yang membutuhkan kritisisme sesuai dengan tuntutan perubahan. Oleh karena itu, hukum keluarga Islam harus senantiasa ditafsir agar responsif dengan persoalan umat tanpa harus kehilangan prinsip dasarnya. Hal ini penting agar hukum keluarga Islam tidak mengalami fosilisasi), dan pada gilirannya akan kehilangan aktualitanya dan ditinggalkan oleh umat Islam sendiri.

Ketidaksanggupan dan kebancian ahli hukum Islam memberikan jawaban terhadap problema kontemporer yang muncul di tengah-tengah masyarakat, dikhawatirkan suatu ketika daya adaptability dan responsibility hukum keluarga Islam dipertanyakan oleh umat Islam. Ini suatu keniscayaan jika umat Islam terus terpasung dalam paradigma ortodoksi yang tidak sesuai dengan perkembangan kemodernan. Indikasi dari kecenderungan ini adalah adanya upaya kalangan Muslim sekuler

${ }^{26}$ Mahsun Fuad, Hukum Islam Indonesia: dari Nalar Partisipatoris Hingga Emansipatoris (Yogyakarta: LKiS, 2005), 271. 
yang mengadopsi sistem hukum keluarga Barat secara mentahmentah untuk diterapkan bagi umat Islam.

Dalam konteks pembaruan hukum Islam dalam hukum keluarga di Indonesia, menampakkan potret pembaruan yang unik sekaligus problematik. Dikatakan demikian karena di Indonesia berlaku tiga sistem hukum, yaitu hukum adat, hukum Islam dan hukum Barat. Ketiga sistem hukum ini, menurut Hooker tidak ada satupun sistem hukum yang saling menyisihkan. Di lain pihak, kesamaan derajat berlakunya ketiga sistem hukum ini tidak selamanya berjalan dalam jalur yang searah. Akan tetapi, pada situasi dan kondisi tertentu kadangkala ketiga sistem hukum ini berada dalam konflik. ${ }^{27}$ Konflik ketiga sistem hukum yang berlaku di Indonesia, pada akhirnya melahirkan ketegangan. Ketegangan yang terjadi antara ketiganya pada gilirannya menjadi problem yang serius dalam pembaruan hukum Islam di Indonesia.

Dengan demikian, pembaruan hukum Islam dalam hukum keluarga di Indonesia tidak tunggal dan berdiri sendiri. Akan tetapi, selalu konfiguratif dengan aspek-aspek yang mengitarinya. Aspek-aspek yang terkait dengan pembaruan hukum keluarga di Indonesia, antara lain:

\section{Aspek Material}

Setelah bangsa Indonesia menyatakan kemerdekaannya pada tanggal 17 Agustus 1945, pembaruan materi hukum mulai dilakukan. Hal ini dimaksudkan untuk mengganti hukum warisan kolonial Belanda yang bertentangan dengan konstitusi Negara Indonesia merdeka. Menurut Hazairin, setelah proklamasi kemerdekaan Indonesia dan UUD 1945 dijadikan sebagai konstitusi Negara, maka semua peraturan perundanganundangan Hindia Belanda tidak berlaku lagi. ${ }^{28}$ Dengan demikian, pembaruan materi hukum di Indonesia dimaksudkan untuk mengganti produk-produk hukum yang diwariskan oleh pemerintahan kolonial Belanda yang tidak sesuai lagi dengan

27Imam Syaukani, Rekonstruksi Epistemologi Hukum Islam dan Relevansinya dengan Pembangunan Hukum Nasional (Jakarta: Raja Grafindo Persada, 2006), 88 .

28Ibid., 81. 
prinsip-prinsip yang terkandung dalam Pancasila dan UndangUndang Dasar 1945. Hal ini penting karena beberapa produk hukum kolonial Belanda yang sampai saat ini tetap berlaku sudah tidak sesuai lagi dengan prinsip-prinsip dasar negara Indonesia yang merdeka.

Dalam kerangka pembaruan hukum keluarga Indonesia, hukum Islam meempunyai peran yang sangat penting dan strategis. Dikatakan demikian karena hukum keluarga Islam, di samping diakui sebagai sumber hukum secara yuridis, juga mempunyai prinsip-prinsip yang universal serta sesuai dengan kepribadian bangsa Indonesia. Bahkan, secara sosiologis hukum keluarga Islam telah mengakar dan menjadi hukum yang hidup di tengah-tengah mayoritas masyarakat Indonesia.

Realitas hukum Islam sebagai sumber hukum di Indonesia tersebut, menempatkannya pada posisi yang eksistensial dalam konteks pembaruan materi hukum keluarga. Paling tidak, didukung oleh dua argumen, yaitu: pertama, hukum keluarga Islam dibangun di atas prinsip-prinsip universal, sehingga memungkinkan diterjemahkan secara substantif dalam pembaruan sistem hukum keluarga Indonesia. Itu berarti bahwa nilai-nilai substansial hukum keluarga Islam mengilhami pembaruan hukum keluarga di Indonesia, seperti beberapa pasal dalam Undang-Undang Nomor 1 Tahun 1974 tentang Perkawinan, PP No. 9 tahun 1975, PP No.10 Tahun 1983 tentang Izin Perkawinan dan Peceraian Bagi Pegawai Negeri Sipil serta No. 45 Tahun 1983 tentang Izin Perkawinan dan Perceraian Pegawai Negeri Sipil.

Kedua, pembaruan materi hukum keluarga Islam dalam sistem hukum keluarga di Indonesia, dapat dilakukan dengan menetapkan materi hukum keluarga Islam sebagai peraturan perundang-undangan yang berlaku secara positif. Dalam artian bahwa pembaruan materi hukum Islam sebagai hasil pemikiran ulama secara kolektif (jama'i) ditetapkan sebagai hukum positif, seperti Inpres No. 1 Tahun 1991 tentang Kompilasi Hukum Islam. Bahkan, pembaruan materi hukum keluarga Islam dapat dilakukan melalui ijtihad individual dan diajukan untuk ditetapkan sebagai peraturan perundang-undangan untuk mengganti beberapa materi hukum yang telah berlaku, seperti 
yang dilakukan oleh Munawir Sjadzali melalui gagasan reaktualisasi hukum Islam dan Musda Mulia melalui Counter of Legal Draft KHI.

\section{Aspek Metodologis}

Pembaruan hukum Islam dalam konteks hukum keluarga di Indonesia, bukan persoalan yang mudah. Paling tidak, dapat dilihat dari dua aspek, yaitu:

a. Kondisi objektif masyarakat Indonesia yang pluralistik harus menjadi salah satu variabel pertimbangan. Hal ini penting untuk menghindari pembaruan hukum Islam yang kontra produktif sehingga merugikan umat Islam sendiri.

b. Pembaruan hukum yang dilakukan harus memperhatikan aspek metode perumusan hukum Islam dalam kontek pembaruan hukum keluarga Indonesia. Hal ini dimaksudkan agar formulasi hukum Islam yang dirumuskan tidak bertentangan dengan kesadaran dan karakteristik hukum nasional. ${ }^{29}$

Dalam konteks pembaruan hukum Islam, aspek metodologi dipandang sebagai faktor yang menentukan wujud hukum (hasil ijtihad) yang dilakukan. Oleh karena itu, dalam kerangka pembaruan hukum keluarga Islam di Indonesia yang sesuai dengan kesadaran hukum masyarakat dan sesuai dengan karakteristik hukum nasional, dapat digunakan beberapa pendekatan, yaitu:

1) Pendekatan historis

Pendekatan historis dimaksudkan untuk mengetahui latarbelakang sejarah suatu produk hukum. Penerapan pendekatan historis dalam pembaruan hukum keluarga di Indonesia dapat dilihat pada ketentuan pasal 2 ayat 2 UU No. 1 Tahun 1974 tentang Perkawinan dan pasal 6 ayat 1 dan 2 KHI yang mengatur tentang ketentuan pencatatan perkawinan. Dalam kitab-kitab fiqh klasik tidak ditemukan ketentuan tentang pencatatan perkawinan. Menurut Ahmad Rofiq bahwa tidak ditemukannya ketentuan pencatatan perkawinan dalam kitab-kitab fiqh klasik karena pada waktu

${ }^{29}$ Ibid., 251. 
itu tingkat amanah kaum Muslimin masih tinggi, sehingga kemungkinan penyelewengan perkawinan relatif kecil. ${ }^{30}$ Dengan demikian, seiring dengan perkembangan masyarakat yang semakin modern dan semakin kompleksnya problema masyarakat, maka ketentuan pencatatan perkawinan menemukan vitalitasnya.

2) Pendekatan maslahah

Tingkat kemaslahatan suatu rumusan pembaruan hukum keluarga Islam di Indonesia, idealnya dijadikan sebagai ruh dari setiap ketentuan hukum. Oleh karena itu, ketentuan pencatatan perkawinan dipandang sebagai prestasi brilian para pakar hukum Islam di Indonesia. Dikatakan demikian karena pencatatan perkawinan mengandung nilai kemaslahatan yang tinggi dan merupakan solusi hukum atas merebaknya perkawinan di bawah tangan (baca; nikah sirri). ${ }^{31}$ Dengan demikian, berdasarkan pertimbangan maslahat dapat dikatakan bahwa perkawinan di bawah tangan adalah tidak sah karena di samping bertentangan dengan ketentuan hukum positif Indonesia juga bertentangan ruh syariat.

3) Pendekatan realitas sosial

Pendekatan realitas sosial secara konseptual dimaknai sebagai upaya melakukan pembaruan hukum dengan menghadirkan pendekatan realitas sosial dan pendekatan lainnya secara simultan dalam merumuskan (istinbat) hukum. Artinya bahwa dalam kerangka pembaruan hukum keluarga Islam, realitas sosial menjadi salah satu variabel dalam proses analisis atau penemuan hukum, sehingga suatu hukum tidak hanya diderivikasi dari teks. Penerapan pendekatan realitas empiris dalam pembaruan hukum keluarga di Indonesia dapat dilihat pada beberapa ketentuan hukum dalam KHI, seperti ketentuan harta orang tua yang dihibahkan kepada anaknya dan setelah orang tua meninggal harta hibah tersebut diperhitungkan sebagai warisan bagi anak yang bersangkutan. Ketentuan yang demikian tidak ditemukan

${ }^{30}$ Ahmad Rofiq, Pembaharuan Hukum Islam di Indonesia (Jakarta: Raja Grafindo Persada, 1995), 106-7.

31Syaukani, Rekonstruksi Epistemologi, 255. 
dalam literatur fiqh klasik dan hanya ditemukan dalam hukum adat sebagai realitas sosial.

\section{Aspek Sosiologis}

Dalam konteks pembaruan hukum, aspek sosiologis yang senantiasa mengalami perkembangan dari waktu ke waktu dipandang sebagai salah aspek yang mengiringi proses pembaruan hukum. Aspek-aspek sosiologis yang mengiringi pembaruan hukum Islam dalam hukum keluarga di Indonesia, antara lain:

1. Pranata kekerabatan berfungsi sebagai pemenuhan kebutuhan pemeliharaan dan pengembangan keturunan (reproduksi). Untuk memelihara dan mengembangkan kebudayaan yang dianut secara kolektif. Untuk memenuhi kebutuhan itu dilakukan penataan hubungan antarindividu di dalam lingkungan keluarga, sebagai organisasi sosial terkecil. Pranata itu mengalokasikan nilai dan kaidah al-abwāl alshakhsiyah, yang berkenaan dengan penerimaan anggota keluarga baru melalui tahapan pelamaran dan perkawinan; hak dan kewajiban suami istri dalam kehidupan keluarga; pengaturan kelahiran; pengasuhan dan pendidikan anak; pengaturan harta kekayaan perkawinan; perceraian; dan pengoperalihan hak-hak pemilikan harta apabila anggota keluarga meninggal dunia (perihal kewarisan). ${ }^{32}$

2. Pranata pendidikan, berfungsi sebagai pemenuhan kebutuhan dalam mensosialisasikan keyakinan, nilai-nilai dan kaidahkaidah yang dianut oleh suatu generasi kepada generasi berikutnya. Selanjutnya, sosialisasi itu meliputi informasiinformasi baru dan berbagai aspek yang dibutuhkan di dalam kehidupan masyarakat. Untuk memenuhi kebutuhan

32Di dalam masyarakat bangsa Indonesia dewasa ini fungsi-fungsi keluarga semakin berkembang, di antaranya fungsi keagamaan, yang mendorong dikembangkannya keluarga dan seluruh anggota nya menjadi insan-insan agamis yang penuh iman dan taqwa kepada Tuhan Yang Maha Esa. Pengaturan kehidupan keluarga dalam hal ini perkawinan, diatur menurut ketentuan peraturan perundang-undangan yaitu undang-undang Nomor 1 tahun 1974 tentang perkawinan dan berbagai peraturan pelaksanaannya. Alokasi hukum Islam di dalam peraturan itu sangat besar, bahkan dominan. 
tersebut, dilakukan pengaturan yang berkenaan dengan jalur, jenis dan jenjang pendidikan. Dengan demikian, tingkat pendidikan menjadi faktor yang menentukan dalam proses pembaruan hukum di Indonesia.

3. Pranata keilmuan, berfungsi sebagai pemenuhan kebutuhan dalam mengembangkan pemahaman terhadap ayat-ayat Allah, yaitu ayat-ayat qawliyah dan ayat-ayat kawniyah. Ayatayat al-Qur'an yang pertama kali diterima Rasulullah Saw. (S. al-Alaq: 1-5) memberikan petunjuk tentang keharusan "membaca" ciptaan Allah Swt. Untuk memenuhi kebutuhan itu dilakukan penataan tentang sumber, substansi, metode, dan kegunaan hasil pemahaman tersebut. Hasil pemahaman itu disebarluaskan dalam berbagai karya ilmiah di antaranya dalam kitab-kitab fiqh dalam berbagai aliran pemikiran (mazhab)..$^{33}$

4. Pranata politik, berfungsi sebagai pemenuhan medium dalam melakukan pembaruan hukum keluarga di Indonesia melalui artikulasi politik di dalam kehidupan masyarakat, berbangsa dan bernegara. Artikulasi politik itu dilakukan melalui infra dan supra struktur politik. Untuk memenuhi kebutuhan pembaruan hukum, maka dilakukan penataan kehidupan politik melalui keputusan kekuasaan negara. Dengan demikian, semakin baik sistem politik yang dianut oleh suatu Negara, maka semakin baik pula peluang pembaruan hukum

${ }^{33}$ Adanya berbagai mazhab figh, umpamanya menunjukkan bahwa di dalam masyarakat Islam Indonesia dikenal pranata keilmuan, dengan ulama sebagai sentralnya. Ia merupakan pengembangan suatu kegiatan intelektual yang dilakukan dengan menggunakan metode dan pendekatan tertentu secara konsisten. Kegiatan itu berlangsung secara berkelanjutan, yang kemudian dikalangan antropolg dikenal sebagai tradisi tradisi besar (great tradition). Pusat-pusat pengkajian tumbuh dan berkembang terutama dalam lingkungan pesantren, perguruan tinggi, dan lembaga swadaya msyarakat. Demikian halnya, pengkajian dilakukan dalam lingkungan organisasi kemasyarakatan, misalnya dalam lingkungan MUI dilaksanakan oleh Komisi Pengkajian Masalah Keagamaan. Oleh karena itu, dikalangan umta Islam Indonesia dikenal pranata keulamaan sebagai simbol pewaris para nabi. Ulama, sebagai kelompok elite dalam komunitas Islam di Indonesia memiliki karakteristik sendiri, serta memiliki peranan yang sangat penting dalam perkembangan masyarakat bangsa Indonesia. 
Islam untuk ditetapkan sebagai hukum keluarga secara positif.

5. Pranata bukum, berfungsi untuk memberikan legitimasi yuridis pembaruan hukum Islam dalam hukum keluarga Indonesia. Sebagaimana diketahui bahwa konstitusi Negara (UUD 1945) memberikan legitimasi yang kuat bagi pembaruan hukum keluarga Islam untuk ditetapkan sebagai hukum nasional.

\section{Catatan Akhir}

Gagasan tentang fiqh Indonesia yang dimunculkan oleh sejumlah tokoh intelektual Indonesia, nampaknya dapat memberikan fenomena baru bagi perkembangan hukum Islam di Indonesia. Rumusan figh Indonesia menurut penggagasnya, sebenarnya sudah menampilkan suatu rumusan yang oprasional dan mendekati sempurna, namun demikian gagasan tersebut perlu adanya dukungan dan langkah-langkah ke arah konsep yang lebih sempurna seiring dengan kemajuan zaman dan dinamika masyarakat. Maka salah satu hal yang perlu dikembangkan untuk merespon berbagai persoalan umat di Indonesia adalah 'urf. Menurut Hasbi, 'urf yang menjadi salah satu sumber hukum ialah adat kebiasan yang dipandang baik oleh akal sehat dan dapat diterima oleh tabiat manusia. ${ }^{34}$ Para fuqaha' dalam mengeluarkan fatwā hukum, banyak berdasarkan "urf di lingkungan masyarakatnya. ${ }^{35}$ Selanjutnya, dalam menggunakan 'urf sebagai sumber hukum, timbul permasalahan 'urf mana yang dijadikan sebagai norma dan patokan. Apakah 'urf Arab, Mesir, Irak, India yang telah ditransfer ulama-ulama dahulu ke dalam kitab-kitab fiqh yang mereka susun? Padahal pepatah Indonesia mengatakan: "Lain lubuk lain ikannya, lain

${ }_{34}$ Hasbi As Shiddiqy, Pokok-pokok Ilmu Dirayah Hadis, vol. 1 (Jakarta: Bulan Bintang, 1981), 34.

35 Menurut Azhar Basyir, 'Urf itu ada dua macam. "Urf shabih dan urf fasid. Dalam hal ini, yang pertamalah yang dapat dijadikan sebagai dasar penentuan hukum, yakni 'urf/adat istiadat yang dapat diterima oleh masyarakat luas, dibenarkan oleh akal sehat, membawa kemaslahatan serta tidak menyalahi ketentuan nash al-Qur'an dan Sunnah Rasul. Lihat Ahmad Azhar Basyir, "Pokok-pokok Ijtihad dalam Hukum Islam," in Ijtihad dalam Sorotan, ed. Jalaludin Rahmat (Bandung:: Mizan, 1992), 52. 
ladang lain belalang". Pepatah Jawa mengatakan: "Seje deso mowo coro". Maksudnya tidaklah sama "urf dari setiap bangsa. Masingmasing bangsa mempunyai 'urf sendiri-sendiri yang merupakan bagian dari struktur kebudayaan mereka.

Dari uraian yang telah dikemukakan di atas, ditarik beberapa point simpulan sebagai berikut:

1. Dinamika kehidupan bermasyarakat tidak sepi dari sejumlah persoalan yang ada. Untuk menjawab persoalan yang timbul di masyarakat, hukum keluarga di Indonesia harus dilihat dengan berbagai perspektif.

2. Pembaruan hukum Islam dalam konteks hukum keluarga Indonesia dipandang sebagai amanah konstitusi Negara untuk menggantikan produk-produk hukum kolonial Belanda yang masih berlaku dan untuk menggantikan beberapa produk hukum yang dipandang tidak sesuai dengan tuntutan perubahan.

3. Pembaruan hukum Islam dalam konteks hukum keluarga Indonesia meliputi empat kategori, yaitu; fiqh, fatwā, yurisprudensi dan perundang-undangan.

4. Aspek-aspek yang terkait dengan pembahuruan hukum Islam dalam hukum keluarga Indonesia, antara lain: aspek materil, aspek metodologis, dan aspek sosiologis.

\section{Daftar Pustaka}

al-Jawziyah, Ibn al-Qayyim. I'lam al-Muwaqqin 'an Rabb al'Alamin. Vol. 3. Beirut: Dār al-Fikr, t.th.

al-Shathībī, Abū Ishạā. al-Muñäfaquàt fì Usūul al-Sharāah. Edited by Tahqiq Abdullah Daraz. Vol. 2. Beirut: Dār al-Kutub al'Ilmiyyah, t.th.

Ali, Muhammad Daud. Hukum Islam dan Peradilan Agama: Kumpulan Tulisan. Jakarta: Raja Grafindo Persada, 1997.

Anderson, J.N.D. Islamic Law in Modern World. Translated by Machnun Husain. Surabaya: Amar Press, 1991.

As Shiddiqiy, Hasbi. Syariat Islam Menjawab Tantangan Zaman. Jakarta: Bulan Bintang, 1996.

As Shiddiqy, Hasbi. Pokok-pokok Ilmu Dirayah Hadis. Vol. 1. Jakarta: Bulan Bintang, 1981. 
Basyir, Ahmad Azhar. "Pokok-pokok Ijtihad dalam Hukum Islam." In Ijtihad dalam Sorotan, edited by Jalaludin Rahmat. Bandung:: Mizan, 1992.

Bisri, Cik Hasan. Hukum Islam dalam Tatanan Masyarakat Indonesia. Jakarta: Logos, 1988.

Djatnika, Rahmat. "Jalan Mencari Hukum Islam Upaya Ke Arah Pemahaman Metodologi Ijtihad." In Dimensi Hukum Islam Dalam Sistem Hukum Nasional, edited by Amrullah Ahmad SF. Jakarta: Gema Insani Press, 1996.

Fuad, Mahsun. Hukum Islam Indonesia: dari Nalar Partisipatoris Hingga Emansipatoris. Yogyakarta: LKiS, 2005.

Hanafi, Ahmad. Sejarah dan Pengantar Hukum Islam. Jakarta: Bulan Bintang, 1986.

Harahap, M. Hahya. "Informasi Materi Kompilasi Hukum Islam: Mempositifkan Abstraksi Hukum Islam." In Kompilasi Hukum Islam dan Peradilan Agama dalam Sistem Hukum Nasional, edited by Cik Hasan Bisri. Jakarta: Logos Wacana Ilmu, 1999.

Hazairin. Tujub Serangkai tentang Hukum. Jakarta: Tintamas, 1974. Hosen, Ibrahim. "Pemerintah sebagai Mazhab." Pesantren 2, no. 2 (1985): 45.

Jazuli, A. Ilmu Figh: sebuah Pengantar. Bandung: Orba Shakti, 1991.

Mudzhar, Muh. Atho. Fatwā-Fatwā Majelis Ulama. Jakarta: INIS, 1993.

Rofiq, Ahmad. Pembaharuan Hukum Islam di Indonesia. Jakarta: Raja Grafindo Persada, 1995.

Syaukani, Imam. Rekonstruksi Epistemologi Hukum Islam dan Relevansinya dengan Pembangunan Hukum Nasional. Jakarta: Raja Grafindo Persada, 2006.

Wahid, Marzuki and Rumadi. Fiqh Mą̧ab Negara. Yogyakarta: LKiS, 2001.

Yafie, Ali. "Matarantai yang Hilang." Pesantren 2, no. 2 (1985): 30. ------. Menggagas Fiqh Sosial. Jakarta: Logos Wacana Ilmu, 1995. 